\title{
Aesthetic and Cultural Approach to the Change in the Making Techniques of Karagöz Figures
}

\author{
Karagöz Tasvir Yapım Tekniklerindeki Değişime Estetik ve Kültürel Yaklaşım
}

\author{
Duygu Ebru Öngen Corsini*
}

\begin{abstract}
Karagöz developed as a unique culture in Anatolian lands. Despite many controversies about how Karagöz came into existence, there is a consensus that it emerged in the $16^{\text {th }}$ century. Figures, as cultural objects, have production methods and techniques interwoven with the doctrines of the past. Today, figure-making for different purposes, inherited from the past, is present in Karagöz figure art. The aesthetic reflections, technique, and material harmony of the figures for show purposes must carry the cultural essence of Karagöz. This study examines museum collections and exhibitions, interviews with Karagöz masters, and a data analysis from an academic perspective. Considering these factors, it becomes clear that the training of masters for figure-making art is significant. Long-term training organized by institutions will contribute to this art and might be beneficial for good examples to reach the audience. Transferring the figures to future generations while preserving their cultural essence, making them in a suitable technique, and aesthetic understanding synthesized with modern techniques; will also contribute to the survival of this art.
\end{abstract}

\section{Keywords}

Karagöz, Figures of Karagöz, Making of Figures, Turkish Shadow Puppetry, Cultural Heritage

\section{Öz}

Karagöz, Anadolu topraklarında kendine özgü bir kültür olarak gelişmiştir. Karagöz'ün oluşum süreci, nelerden beslendiği ve nasıl bir evrim geçirdiği ile ilgili çok sayıda görüş olmasına rağmen 16. yüzyılda geliştiği düşünülmektedir. Tasvirler, kültürel bir obje olarak geçmişten gelen öğretilerle örülü yapım tekniklerine ve yöntemlerine sahiptir. Günümüzde geçmişten devralınan Karagöz tasvir sanatında farklı amaçlara da yönelik tasvir yapımlarıyla karşılaşılmaktadır. Özellikle gösteri amaçlı tasvirlerin estetik yansımalarının ve teknik ve malzeme uyumunun Karagöz'ün kültürel özününü taşıması önemlidir. Bu çalışmada müze koleksiyonları ve sergiler incelenmiş, karagöz ustaları ile saha görüşmeleri yapılmış ve elde edilen veriler akademik bir bakış açısıyla analiz edilmiştir. Söz konusu unsurlar değerlendirildiğinde tasvir yapım sanatı için yetiştirilecek ustaların eğitiminin oldukça önemli olduğu görülmektedir. Kurumların düzenleyeceği uzun soluklu eğitimler, bu sanata katkıda bulunacak, iyi örneklerin seyirci ile buluşmasına da yararlı olacaktır. Tasvirlerin gelecek nesillere kültürel özü korunarak aktarılması, günümüz teknikleriyle sentezlenmiş uygun bir teknik ve estetik bir anlayış içinde yapılması sanatın yaşatılmasına da katkı sağlayacaktır.

\section{Anahtar Kelimeler}

Karagöz, Karagöz Tasviri, Tasvir Yapımı, Türk Gölge Oyunu, Kültürel Miras

* Correspondence to: Duygu Ebru Öngen Corsini (Asst. Prof.) Izmir University of Economics, Faculty of Fine Arts and Design, Department of Textile and Fashion Design, İzmir, Turkey. E-mail: ebrucorsini@hotmail.com, ORCID: 0000-0002-4952-541X

To cite this article: Ongen Corsini, Duygu Ebru. "Aesthetic and Cultural Approach to the Change in the Making Techniques of Karagöz Figures." Art-Sanat, 16(2021): 437-463. https://doi.org/10.26650/artsanat.2021.16.0015 


\section{$\underline{\text { Genisletilmis } \ddot{O ̈}_{z} \text { et }}$}

Karagöz, Anadolu topraklarında kendine özgü bir oyun türü olarak ortaya çıkmıştır. Toplumun alışkanlık, gelenek görenek, kültürel etkileşimleri ve daha pek çok öge Karagöz oyunlarında yansımalarını bulmuştur. Bu yansımalar tasvirler yoluyla yüzyıllar boyunca gelecek nesillere taşınmıştır. Türk kültürü içinde kabul gören Karagöz, Unesco tarafından 2009 yılında "İnsanlığın Somut Olmayan Kültürel Miras Listesi”nde yer almıştır. 16. yüzyıldan itibaren geleneksel yöntemlerle şekillenen ve usta çırak ilişkisi içinde bilgi ve becerilerin nesilden nesile aktarıldığı Karagöz oyunlarının görsel zenginliğini oluşturan Karagöz tasvirleri, 21. yüzyıl yaşam dinamikleri çerçevesinde değişim göstermiştir.

$\mathrm{Bu}$ çalışma, Karagöz oyunlarında kullanılan tasvirlerin geleneksel verilerle güncel olan arasında yeni tip yüzeyler üzerine yapılan uygulamaların yarattı̆̆ 1 görsel etkileri renk ve biçim açısından ele almayı amaçlamaktadır. Karagöz tasvirlerinin yapım amaçlarına göre sınıflandırılmasına, gösterim amaçlı tasvirlerin günümüzde kullanılmakta olan tekniklerle gelecek nesillerde karşılaşılabilecek görsel kayıplara dikkat çekmeyi hedeflemektedir. Çalışmada nitel araştırma yöntemi kullanılmıştır. Araştırmanın ilk aşmasında; literatür taraması ile veri analizi yapılmış, müzelerde yer alan Karagöz tasvirleri incelenerek film, resim, fotoğraflarla görsel kaynaklar değerlendirilmiştir. İkinci aşamada ise; Karagöz ustaları ile derinlemesine görüşmeler yapılmıştır. Bunun sonucunda elde edilen bulgular yorumlanmıştır. Son olarak araştırmanın her iki aşamasından elde edilen bulgular analiz edilmiştir.

Günümüzde Karagöz tasvirlerinin Karagöz oyunlarının yanı sıra turistik ve eğitsel amaçlı farklı kullanımlarına da rastlanmaktadır. Yapım amaçlarına göre Karagöz tasvirlerinin teknik ve biçimsel farklılıkları "Turistik amaçlı", "Eğitsel amaçlı" ve "Gösteri amaçlı" olarak yapım amaçlarına göre sınıflandırarak incelenebilir. Turistik amaçlı tasvirler kendi içinde yapım, boyut ve malzeme özellikleri ve kalite açısından çok geniş bir yelpazeye sahiptir. Turistik amaçlı tasvirler, gösteri amaçlı olanlardan bu açıdan farklılık gösterir. Bu tür içinde yapımı gerçekleştirilen tasvirlerin hediyelik kapsamında farkındalık uyandırmak amacı ile genel olarak hızla üretildiği ve yapım aşamalarının sürece yayılmadığı görülür. Eğitsel amaçlı yapılan tasvirler, Karagöz tasvirlerini gelecek nesillere taşımaya yönelik yapılan çalışmaların bütünü olarak tanımlanabilir. Ulusal ve uluslararası eğitimler tasvir yapımı konusunda yeni Karagöz ustalarının yetiştirilmesi amacı taşır. Yapılan projeler, akademik çalışmalar, workshoplar da bu süreçlere çok farklı yaş gruplarının katılımı ile katkı sağlar. Eğitimler sırasında kullanılan malzemelerde görülen çeşitlilik, eğitimin süresine göre de değişkenlik gösterir. Eğitsel amaçlı tasvir çalışmaları, Karagöz oyunlarının yaşatılmasına yönelik bilgi aktarımını gerçekleştirir. Gösteri amaçlı Karagöz tasvirleri Karagöz sanatının sunumu sırasında kullanılan tasvirlerdir. Bu tasvirlerin Karagöz sanatının tüm inceliklerini taşıması ve yansıtması amaçlanmaktadır. Geleneksel olarak Karagöz tasvirlerinin yapımına dair 
incelikli bilgilerin geçmişte, nesilden nesile ustalar yoluyla aktarıldığı görülmektedir. Günümüzde ise bu gelenek devam etse de üniversiteler ve farklı kurumlar tarafindan da eğitimler verilmektedir. Her aşaması emek isteyen, hevesten çok derinleşerek öğrenilmesi gereken tasvir yapımı aynı zamanda sabır ve saygıya dayanır. Bu nedenle tasvir yapımı için gerekli doğru malzeme seçimi, yüzeyin tasvire hazırlanması, Karagöz kalıplarının çizilmesi ve yüzeylere aktarılması, nevrekânlama ile açılan ışık çizgileri, renklendirme, sabitleme gibi aşamalardan geçerken seyirci ile buluşacak tasvirlerin estetik kaygıları taşımaları, sanatın içeriklerini içselleştirmeleri hayati bir öneme sahiptir. Gösteri amaçlı yapılan tasvirler turistik ve eğitim amaçlı tasvirlerden detaylı ve özenli yapıları ile ayrılmaktadır. Bu tasvirler, ustaların sanatsal deneyimlerini perdeye taşır. Her bir tasvir taşıdığı karakteristik özellikleri ile ustasını yansıtır. Her tasvirin oyunun bütününe sağladığg görsel katkı bir araya getirildiğinde perde yüzeyinde oluşacak ahenk, ilişki, hareket olanakları göz önüne alındığında yüzyıllarca özellikle deve, düve derisinin tercih edildiği görülür. Günümüzde özellikle deriye alternatif oluşturabilecek plastik türevi malzemeler de denenmektedir. Gösteri amaçlı tasvirler boyut olarak yine geleneksel ölçüler çerçevesinde yapılmakla birlikte çok sayıda seyircinin bulunduğu büyük salonlarda düzenlenen gösterilerde tasvirlerin boyutlarının büyütüldüğü görülmektedir. Tasvirlerin kalıp çizimlerinde geleneksel çizgiler, ustanın kendi çizgileri ile yeniden şekillenmektedir. Böylelikle tasvir ustalarının sanatçı yapıları birbirlerinden ayrılır. Tasvirin kesim ve nevrekânlanması aşaması 1şık çizgileri ile belirlenen beden parçalarını daha canlı ve görünür hâle getirir. Gösteri amaçlı tasvirlerde 1şık çizgileri tasvirin iç oranlarını zenginleştirir. Bu alanların siyah mürekkeple daha da güçlendirilmesi renkleri de belirgin hâle getirir. Bedenin içinden geçen 1şık, tasvire hayat verir. Günümüzde geleneksel olarak doğal mürekkeplerin kullanıldığı tasvirler ustalar arasında değer görmeye devam etse de endüstriyel olarak üretilen mürekkeplere de ilgi oldukça artmıştır. Her iki kullanımın perde yüzeyinde farklı etkiler bıraktı̆̆ da bir gerçektir. Tasvire ait tüm parçaların birleştirildiği sabitleme aşaması dikkat gerektiren detaylı bir bölümdür. Tasviri yapan usta aynı zamanda performansı da gerçekleştiriyor ise parçaların gösteri sırasında rahat hareket edebilmesi ve kopma riskinin en aza indirilmesi için farklı tekniklere başvurduğu görülür. Karagöz tasvirlerine bu aşamada yapılan her müdahalenin seyirci tarafından da görüleceği bir gerçektir.

Ustaların elinde şekillenen bu renkli gölgeler sadece bir obje değildir. Tasvirler geçmişten gelen zengin kültürel mirasın rengarenk gölgeleri eşliğinde Türk toplumunun perdeye yansıtılan yüzüdür. Karagöz sanatının en önemli görselleri olan tasvirler geleneksel öğretiler ışığında güncel olanla birleşerek varlığını sürdürmektedir. Geçen sürede tasvirlerde değişim yaşansa da kültürel ve görsel özelliklerini koruduğu görülmektedir. Günümüz koşulları içinde Karagöz tasvir sanatının dejenere olmadan gelecek nesillere ulaşabilmesi için doğru bilgilerin saptanması gerekmektedir. Akademik eğitim ile bu sanata ait teknik ve yöntemler belirlenmeli ve geleneksel yöntemlerden gelen bilgiler bu sürece dâhil edilmelidir. 
Karagözün yaşatılabilmesi, ulusal ve uluslararası tanınırlığının sağlanması için daha çok oyun oynatılabilir. Karagöz oyununun güncel olayları işleyebilecek bir yapıda olması, günümüzde de oynanmasının önünü açmaktadır. Farklı konular için yeni tasvirlere ihtiyaç duyulacağından farklı denemeler de yapılabilir.

Bu çalışma Karagöz tasvir sanatının (tasvir yapım, malzeme, yöntem ve amaçlar) gelecek nesillere aktarılmasında yol gösterici bir sınıflandırma önerisinde bulunmaktadır. Bu noktada belirli tespit ve önerilere yer verilmiştir. Karagöz oyunlarının kültürel özelliklerini koruyarak kendini güncellemesi ve geleceğe taşınabilmesi için yeni araştırmalara ve çalışmalara ihtiyaç duyulmaktadır. 


\section{Introduction}

Karagöz is one of the genres that created the Turkish Folk Theater. Technically, the show consists of a white cotton cloth stretched in front of the audience, a light source behind it, and a single person who directs the whole play. It is an imaginary play of figures moving from behind the screen with rods and constantly redrawn images with their colored shadows on the screen. Karagöz has a structure that renews itself by reflecting subjects that relate to almost everyone in society and the events of the period in which they live. Therefore, "Karagöz has always been a branch of art sensitive towards social events at all times." With its cultural composition, unique structure, and tradition, Karagöz is an internationally accepted art that influences everyone, both local and foreign, in every show environment. In the $21^{\text {st }}$ century, Karagöz, as a piece of cultural heritage, was included in the "Intangible Cultural Heritage List of Humanity"2 by UNESCO in 2009.

Although there are various views about how Karagöz emerged in Anatolia and evolved, it was stated in Metin And's research that the shadow play was brought to Anatolia from Egypt in the $16^{\text {th }}$ century. ${ }^{3}$ This document, which explains Karagöz "in the most extensive and detailed way in the $16^{\text {th }}$ century, which can be found in Sûrnâme-i Hümâyûn, which describes the 1582 festival." 4

Evliya Çelebi's Seyahatname also gives information about Karagöz. It sheds light on its period and the present day with data on the historical development of Karagöz, Karagöz masters, and the methods these masters used in their plays. ${ }^{5}$ Özdemir Nutku also stated that in the $17^{\text {th }}$ century, Evliya Çelebi mentioned the names Karagöz and Hacivat in his Seyahatname. From the Ottoman Palace to Anatolia, Turkish society welcomed the Karagöz shadow play, also widespread in Europe, taking its final form during this period. ${ }^{6}$ Thus, in the light of limited resources, Sevengül Sönmez states that this play genre was named Karagöz in this century. " The Turks have added their creativity and produced a vibrant, colorful and original form." 8

Karagöz preserved its cultural structure within the understanding of tradition until the $18^{\text {th }}$ and $19^{\text {th }}$ century. In the $19^{\text {th }}$ century, during the Westernization of the Ottoman

1 Nilüfer Zeynep Özçörekçi Göl, “Turkish Shadow Theatre Karagöz,” Colours of Shadow, ed. Nilüfer Zeynep Özçörekçi Göl, Trans. Berker Tercüme (Ankara: Ministery of Culture and Tourism Publications, 2008), 26.

2 Unesco Türkiye Milli Komisyonu İnsanlığın Somut Olmayan Kültürel Mirası Temsilî Listesi, Accessed 23 September 2020 https://www.unesco.org.tr/Pages/126/123/UNESCO-\%C4\%B0nsan$1 \% \mathrm{C} 4 \% \mathrm{~B} 1 \% \mathrm{C} 4 \% 9 \mathrm{~F} \% \mathrm{C} 4 \% \mathrm{~B} 1 \mathrm{n}$-Somut-Olmayan-K\%C3\%BClt $\% \mathrm{C} 3 \% \mathrm{BCrel-Miras} \% \mathrm{C} 4 \% \mathrm{~B} 1-\mathrm{Tem}-$ sil $\%$ C3\%AE-.

3 Metin And, Geleneksel Türk Tiyatrosu (İstanbul: İnkılâp Kitabevi, 1985), 275.

4 And, Geleneksel Türk Tiyatrosu, 279.

5 Saim Sakaoğlu, Türk Gölge Oyunu Karagöz (Ankara: Akçağ Yayınları, 2003), 45-49.

6 Özdemir Nutku, Dünya Tiyatrosu Tarihi (İstanbul: Remzi Kitabevi, 1985), 1: 202.

7 Sevengül Sönmez, Karagöz Kitabı (İstanbul: Kitabevi Yayınları, 2000), 13.

8 Murat Ünal, “Türk Halk Tiyatrosunun Sinemaya Etkileri,” Art-Sanat 9 (2018), 341. 
Empire, all styles and rules of the past changed; the Karagöz show also gradually lost its popularity. The public's interest turned towards the theater in the western sense, and the intellectuals of the period, with the influence of westernization, saw traditional theater as a useless genre.

"In 1830, the entry of western music to the Sultan's palace under the administration of Donizetti Pasha of Italy, and the occasional arrival of opera and theaters from Europe to Istanbul, and their performances, the performance of western works in Turkish by some local organizations in Istanbul theaters towards the end of the century, took the intellectual class away from Karagöz. Inevitably, Karagöz had to descend to the level of the people who filled the coffeehouses, and thus jokes, rhymes, misunderstandings, and even the technique of the play became unrecognizable. ${ }^{9}$

Karagöz reaches a modern audience today from the hands of $21^{\text {st }}$-century masters by combining the traditional approach, passed on from one generation to the next, and today's technical possibilities with conventional data.

\section{Method}

This study aims to classify the modern techniques used in figure-making and their visual affects on figures in terms of color and form while evaluating the surface relations of play objects, animals, and Karagöz characters used in modern Karagöz shows from the perspective of the screen and light source.

This study consists of data analysis and literature scanning as well as researching the figures in: Karagöz Figures in the Bursa Metropolitan Municipality Karagoz Museum, the Konak Municipality "Umran Baradan Oyun ve Oyuncak” Museum, the Republic of Turkey Ministry of Culture and Tourism Directorate General of Research and Training "Colors of Shadow" Catalogue of the Karagöz Tasvirs Collection of Information and Documentation Centre of Folk Culture, The Exhibition Catalog of "Gölgenin Tasarımı" (Design of Shadow) by Orhan Kurt and his Karagoz Figures organized by Zeytinburnu Municipality, The Exhibition and the exhibition Catalog of “Hayal ya da Gerçek Şeyh Küşteri' den Hayali Küçük Ali’ye Karagöz” (Karagöz from Dream to Real Sheikh Küşteri’s Imaginary Little Ali) organized by Istanbul Metropolitan Municipality in 2018, and Karagoz Figures in the "Y1ktın Perdeyi Eyledin Vîran" (Torn is the Screen, Shattered is the Screen, the Stage all in Ruins) Yapı Kredi Collection Exhibition, which took place in Yapı Kredi Vedat Nedim Tor Museum. Additionally, for this research, online images were studied, and Karagöz masters Metin Özlen and Deniz Özgökbel shared the figures from their archives. Interviews with Karagöz masters were also part of the study. Also, Suat Veral's Karagöz figure bought on the

9 Nureddin Sevin, Türk Gölge Oyunu (İstanbul: Milli Eğitim Bakanlığı Büyük Türk Yazarları ve Şairleri Komisyonu Yayınları, 1968), 50-51. 
Republic of Turkey Ministry of Culture and Tourism Traditional Hand Arts Online Sales website takes place in this study. The study used a qualitative research method.

\section{Conceptual Framework}

Karagöz is an art form that looks closely at the contemporary life of its period with all its values within the Turkish Folk Theater. The Karagöz figures on the screen show the various cultures and ethnic groups in Istanbul during the Ottoman Empire. Aslıhan Ünlü said, "Indeed, Karagöz plays show the cosmopolitan nature of Anatolia and especially Istanbul in terms of religion, ethnicity, and culture. The plays show people from different walks of life in their environment and sharpen their funny features. They are like documents of the social structure and mentality of that period." 10

Considering that most Karagöz masters made their figures and did not copy them from other sources, the depth of the training received from their masters becomes significant. The master reflects his valuable qualities such as good observation, hand skill, painting ability, and high aesthetic taste in figures. Combined with craft and art, figuratively speaking, the figure incarnates in the hands of the master, and the figures of the play appear in the foreground of the screen surface.

As emphasized by Temel in his article "An Understanding in Stage Design; Less is More" 11 , in Karagöz, the reflected figures and the stage layout designed on the screen depends on visuality, plainness, simplicity and functionality, and the story itself. The artists also visualize the play they perform through figures.

Figures carefully made by the master, who was considered a demonstration tool under the conditions of his time, have reached today in limited numbers. In addition, even though the masters trained with the knowledge of the masters of the period decreased in number, they managed to carry the traditional figure-making to the present day.

Many figures could not be preserved due to their organic structure and have disappeared or been lost over time. However, some of the figures that have survived until today are preserved and exhibited in palace museums, archives of local administrations, and private collections. The Karagöz Museum in Bursa has valuable examples of the Karagöz figure art. The figures in the collections were also examined by researchers and contributed to the field. Yasemin Eken, in her research, "designed an information form to create a catalogue of leather figures. They took pictures of the stated samples and filled the forms. In line with the forms, types, dimensions, tools, technique, colour, and composition properties of the leather figures were obtained."12

10 Aslıhan Ünlü, Türk Tiyatrosunun Antropolojisi (Ankara: Aşina Kitaplar, 2006), 94.

11 Süreyya Temel, "Sahne Tasarımında Bir Anlayış; Az Aslında Çoktur," International Journal of Interdisciplinary and Intercultural Art 3/6 (2018), 206.

12 Yasemin Eken, "Bursa İli Karagöz Müzesinde Yapılan Deri Tasvirlerinin İncelenmesi” (M.A.Thesis, Gazi University, 2020), 53. 
The Karagöz figure is preserved and exhibited in international collections. Exhibiting these works is also very valuable in increasing the interest in the subject, creating new master candidates, and enabling masters to see the works of former masters.

We can encounter the reflections of this cultural heritage in bazaars as souvenirs and in the hands of children carrying the figures made through training, websites, and many other places. Within this framework, it is possible to classify Karagöz figures into three main categories according to their purpose: Karagöz figures made for touristic, educational, and show purposes.

\section{Karagöz Figures for Touristic Purposes}

A country's cultural heritage is one of the most valuable treasures of society. "The fact that the cultural thing belongs to the past (temporal distance) or is located in geography far from the place of residence (spatial distance) causes its attraction. On the other hand, some are attracted to cultural tourism by a mental distance (an effort to understand advanced art and science works)" ${ }^{" 13}$

The bridge created through cultural tourism brings people from different places and cultures together both artistically and culturally. The value of the cultural history and the area of attraction it creates are also crucial for promoting countries. Artistic objects have significant meaning with the visual and cultural impact they carry in this communication network. Karagöz figures, with their visual data, play an essential role in the introduction of Turkish folk culture. Figures can be both artistic and portable souvenir objects.

Karagöz figures are available in Traditional Handicrafts and Book Sales Stores and Virtual Stores of DÖSIMM ${ }^{14}$ (the Republic of Turkey Ministry of Culture and Tourism Revolving Funds Directorate). Karagöz master Suat Veral created the "Zenne" figure for touristic purposes, using burning and cutting techniques on calf leather, which is technically close to its original.

13 Zafer Öter and Osman N. Özdoğan, "Kültür Amaçlı Seyahat Eden Turistlerde Destinasyon İmaj1: Selçuk-Efes Örneği”, Anatolia: A Journal of Tourism Research 16/2 (2005), 128.

14 DÖSIMM, “Geleneksel El Sanatları Online Satış Web Sitesi”, Accessed, 24 September 2020, https://www. ges.gov.tr/tr/. 


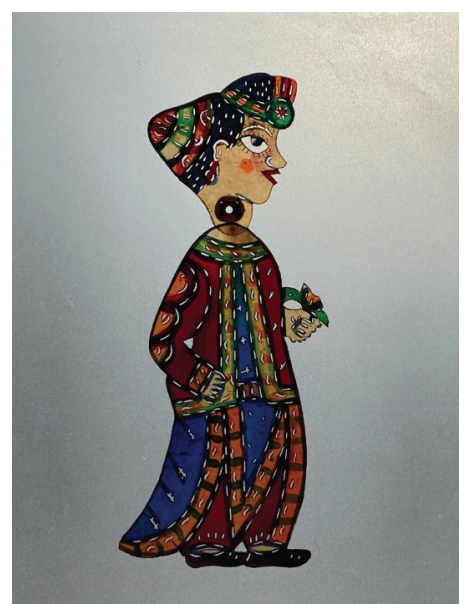

F. 1: “Crowned Zenne” by Suat Veral - (D.E. Öngen Corsini Archive, 2020)

As seen in (F. 1), the form and the size ratio of the figure's eye can be evaluated as a reflection of the stylized eastern aesthetic understanding. The figure is almost usable in a show due to the variety of colors and different cutting techniques. This figure reflects a Karagöz figure used for show but still has minor differences since it is for gift purposes. When considering all these features, it is possible to say that the souvenir figures of Karagöz are different from those used for show purposes.

Although the figures made on leather, PVC, and derivative materials make them remarkable, the construction, size, and material properties are quite different from those for a real show. The production of an actual Karagöz figure is a long process. At this point, it is vital to raise awareness in the scope of gifts. The process accelerates with the techniques used and made suitable for this version. While dyes used in the coloring of the figures rapidly change their surface, they shorten the time that the master spends in the making of the figures. People who want to animate amateur Karagöz are known to use these figures in their plays.

\section{Karagöz Figures For Educational Purpose}

Karagöz figures made for educational purposes can be defined as the whole of the studies to pass on Karagöz to future generations. National and international projects, puppet festivals, educational figure workshops for a few hours in museums, figure-making courses given by masters aimed at training Karagöz masters, and lessons in schools are in the forefront. The projects carried out, including short-term courses, aim to train Karagöz masters. It is seen that figure-making techniques in such training take shape according to the current requirements. In activities carried out according to age groups, the duration and process of the activity, the location of the activity, and the number of people determine the technique used in the making of Karagöz figure. 
Therefore, educational materials vary. In courses for children, the preparation of educational figures usually starts with paper colouring using colored pencils. Specifically in these practices, Karagöz and Hacivat figures have priority, and it is possible to raise children's awareness by informing them of the use of clothing, body, and colors.
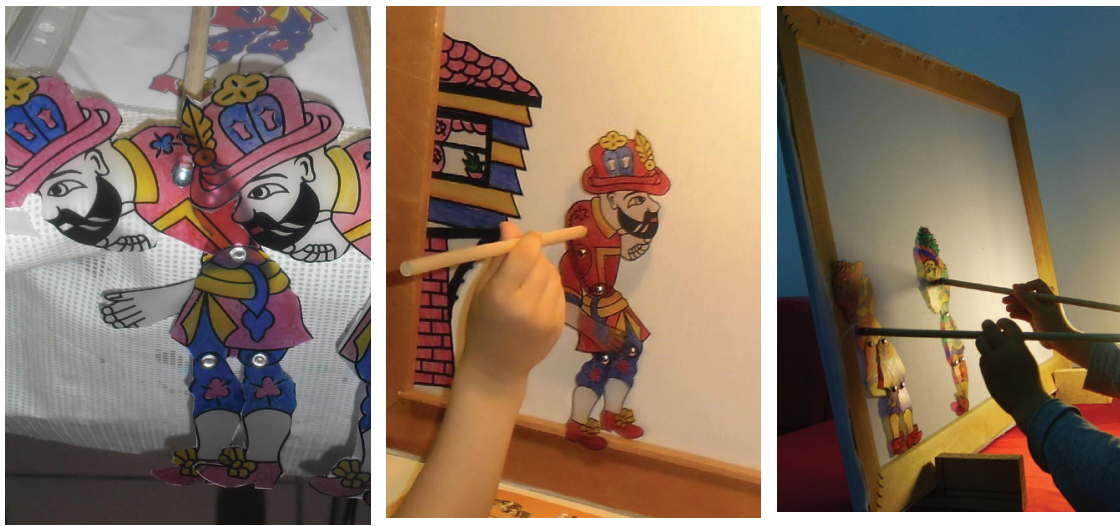

F. 2, F. 3, F. 4: Konak Municipality Ümran Baradan Game and Toy Museum 'Karagöz Workshop-Deniz Özgökbel (D. Özgökbel Archive, 2020)

For example, as can be seen in (F. 2), (F. 3), and (F. 4), Karagöz master Deniz Özgökbel conducted Karagöz plays and training within the scope of the activities organized in the Konak Municipality Ümran Baradan Game and Toy Museum. "The surface to be worked on is in plastic effect, transparent or translucent. It can let light through the colour. It is easy to cut the part with scissors, fixing the separated parts with rivets from the connection points. ${ }^{~}{ }^{15}$ Bamboo sticks are also used as light rods for educational purposes, especially in workshops with children. The materials used in training are for learning technical information. Managing the material requires time and good training. Therefore, in figure-making projects or courses, the participants must complete the course with a master's degree of knowledge and experience in the art of Karagöz for future work.

It is of great importance for Karagöz masters to teach in the courses opened for educational purposes in terms of new figure production that will carry the cultural characteristics of the Karagöz figure-making art. Karagöz Master Ragıp Tuğtekin shares the following information while talking about the lectures he has given on the production of figures: "The enthusiastic friends were the first to participate in the figure-making workshop which was opened as a course in the Undersecretariat of Culture last year. If the course continues, we will also include figure-making and in the future figure-animating style in the program." ${ }^{16}$ In light

15 Deniz Özgökbel, Personal Interview 24 September 2020.

16 Nail Tan, "Karagöz Sanatçısı Ragıp Tuğtekin'le bir Konuşma”, Yıktın Perdeyi Eyledin Vîran Yapı Kredi Karagöz Koleksiyonu, ed. Sabri Koz (İstanbul: Yapı Kredi Yayınları, 2004), 149. 
of this information, it is essential to draw attention to the importance of education in making Karagöz figures.

Leather is the surface material used for the figure in the courses. The rarity of leather and its higher economic value than other materials require careful processing of its surface. While some master candidates can work directly on leather, some master candidates make figures on cardboard, plastic, and PVC surfaces for educational purposes before working with leather. Paper or cardboard is a surface on which people interested in Karagöz shadow plays and who are in the learning phase of figure-making gain experience. This surface needs to be made translucent by going through certain stages.

In his work Karagöz and Our Puppet Art, Hayrettin İvgin shares information on this technique. The white colored cardboard deposited in linseed oil soaks for a few minutes in order to gain transparency. The molds used after the drying process of the cardboard surface are processed, the parts that will transmit light are cut, and the color areas on the surface are determined. Watercolor, oil, and spirit paints are materials used during the coloring process. The part of the moving rods, from which the figure is attached, is strengthened with another piece of cardboard. All parts are tightened together using nylon threads, and the figure is complete for show. In another method, the figure drawn on cardboard, cut, and coloured after opening the light line areas is kept in melted wax for a few minutes until the wax passes into the cardboard under heat treatment. After cleaning the cardboard left to cool and bringing the parts together, the figure is complete. However, another alternative is figures made using acetate. Acetate is suitable for making X-ray film figures. After the visual layer on the X-ray film is cleaned and the transparent surface is ready for the figure drawing, the mold is transferred on the surface, cut, painted, and completed with the assembly process. ${ }^{17}$ In figures made for educational purposes, such applications are generally used in current education as was in the past.

PVC, a plastic material, is rarely used in Karagöz plays for show purposes. The colors of the defective surfaces can be erased and repainted. With their robust structure, they can be resistant to sharp movements and moisture. The dyes used on the figure's surface are different from those applied on the leather's surface. Figures generally have brighter and more vibrant colors depending on the dye and technique.

Hülya Taş stated that short and long-term courses organized by the Ministry of Culture and Tourism or other associations, workshops by local universities or other educational institutions, masters to raise awareness, and all kinds of figure-making workshops for educational purposes within the scope of festivals and festivities are contributions to keep the art of Karagöz figure and Karagoz plays alive. For example,

17 Hayrettin İvgin, Karagöz ve Kukla Sanatımız (Ankara: Ekip Grafik Matbaa Hizmetleri Tic. ve San. Ltd. Şti., 2000), 10-11. 
İsmail Hakk1's interest in painting led him to make figures by participating in the Karagöz Apprenticeship and Performing Seminar course in Bursa in 2000. ${ }^{18}$

\section{Karagöz Figures For Show Purposes}

Although Karagöz figure for touristic and educational purposes is within the scope of the study, the main focus is on the Karagöz figures for show purposes because those who have all the subtleties of Karagöz figures are the ones made for show purposes. Therefore, the study focuses on the figures for show purposes and deals with the others regarding their relation. Therefore, the material used in the making of the figures plays a vital role in providing this visuality. The master can process his figures by extending the making of the figure over some time.

In Karagöz figures for educational purpose, aesthetic concerns and materials are about gaining process experience. Visual aesthetics are of secondary importance in figures for educational purposes. The primary purpose of such figures is to show the figure itself and to learn. Once more, when considering this type of figure in terms of design, construction process, and visual contribution to the play, more explicit materials are chosen to be practical, economical, and easy to produce.

The figures for touristic purposes also vary according to the master's experiences, aesthetic point of view, the materials they use, and their hand skills. The aim is how a Karagöz figure looks and the way the essential details are linked rather than the colored shadow on the screen. The aesthetic appearances of such figures may vary, just like the ones for educational purposes. The production techniques of these figures are present in the figures made for both educational and touristic purposes. While the Karagöz artist is designing and making his figures, the figures used in the shows can also be made by different figure-making masters. When the artist, the performer of the whole play, makes his figures, he also shares his understanding of design with the audience. Karagöz master Şinasi Çelikkol stated that "performing the shadow play and depiction are very different works and that there are very few artists who do both, and he is one of them." 19

There is an expectation that figures which come together with many features such as portraits, lines, shapes, sizes, textures, colors, the light-dark relationship of colors in different figures, and movement abilities are reflected on the screen with embroidery and the grace in light lines in artistic and aesthetic harmony. Figure-making is an art with subtleties. Colorful pictures reflected on the screen will complete the composi-

18 Hülya Taş, “Günümüz Bursa’sında Karagöz”, Uludağ University Fen-Edebiyat Fakültesi Sosyal Bilimler Journal 8/12 (2007), 142.

19 Melda Özdemir and Yasemin Eken, "Bir E1 Sanatları Ürünü Olarak Karagöz Tasvirlerinin Yapımı Ve Hayali Şinasi Çelikkol'un İcra Geleneğindeki Yeri,”' Idil Journal of Art and Language 9/75 (2020), 1606. 
tion created on the screen with the details and embroidery of the figures. The figures are like the signature of the master, who makes proportional and balanced light lines and drawn subtleties. A good figure should have harmonious main lines both on its own and with other figures.

In Karagöz plays, the figures made for show purposes are necessary images for the play. These images go through a research process before preparation. The purpose of the figure, the type of visual features, and all the details that it should have on its two-dimensional surface are considered separately.

It is plausible to study figures for show purposes in terms of material, size, pattern, delineation, coloring, fixation, rod-figure relationship, and aesthetic.

\subsection{Figure Surface Material}

It is a fact that leather is the material used in Karagöz figures for show purposes. The leather should have certain flexibility with its structural form. Collagen fiber bundles are essential for the formation of the thickness of the leather. For this reason, one of the most critical points for making figures is the necessity in the preference for regions with smaller layers of fat. Metin And stated that before starting the process of the making of animal figures mentioned above, it is possible to cut out 30-40 figures from the remaining part of a leather piece after removing the arm, neck and fat belly. ${ }^{20}$ Karagöz Master Orhan Kurt drew attention to the importance and place of camel leather in figure-making because camel leather is suitable for figure-making in terms of its structure, which can take non-deformed paints into the leather, and he also emphasized that the two side pieces of a camel are convenient quality parts for making 30-40 figures. In addition to camel leather, he emphasized donkey leather as another alternative quality leather because of its transparency and treatable structure. ${ }^{21}$

The transparency with the necessary light transmittance and resistance to heat emission by the light source and the homogeneous distribution of collagen on the leather, which retains moisture, also affect the figure's quality. Once the figure is complete, the leather selection should not cause any problems behind the scenes during the play due to its weight or thickness. Sevengül states that the selected leather should be resistant to transparency and sensible heat. ${ }^{22}$ In figures made for show purposes, the dynamism on the surface of the leather, which is the dominant material on the figure surface, will be reflected in a wavy visual form with distorted proportion and color integrity on the screen surface like a colorful painting. As an organic material, leather is naturally

20 Metin And, Dünyada ve Bizde Gölge Oyunu (Ankara: Türkiye İş Bankası Kültür Yayınları, 1977), 289.

21 Orhan Kurt, Karagöz'ün Kuralları Karagöz Yapım ve Oynatım Teknikleri (İstanbul: Lale Yayıncılık, 2015), 39. 22 Sönmez, Karagöz Kitabl, 41. 
prone to extinction. Suitable productions, the leather structure, and all details in the painting process will ensure the durability of the figure.

A trend towards plastic and its derivatives has begun among the masters of figures. Apart from leather, Ali Kurna paper and plastic surface materials, whose light transmittance by waxing, are also prefered materials for figure-making. " Leather has been used the most in the past and today, and for the same reason, plastic sheets are gaining more and more importance." 23

Karagöz Master Ünver Oral Karagöz says that using the plastic technique in the production of figures could overcome the obstacles and difficulties that arise in order for Karagöz to continue existing in the future. He states that with this method, the figures will not be affected by heat like leather, the dyes used can be wiped, scraped, and repainted, and the figure ratios can be larger according to the thickness of the plate. Compared to leather, plastic provides more flexibility and ease in moving parts of the body. ${ }^{24}$ Despite the controversial ideas on these applications, leather is the prefered material in making the traditional figures for show purposes.

\subsection{Dimensions Of The Figures}

Different dimensional features appear when evaluating the traditional Karagöz figures and recent shows regarding space and audience relationship.

Nureddin Sevin said, "The figures of the Turkish shadow play, which we call Karagöz, do not exceed thirty or thirty-five centimeters in height. This size allows them to have graceful and agile movements with ease. Karagöz figures are like miniatures in motion." ${ }^{25}$ According to the information we received from Şapolyo, the measurements used in classical figures in Karagöz plays, as a tradition from the past, are 25 or $30 \mathrm{~cm}$ tall. These figures were neither larger nor smaller. ${ }^{26}$ Nilüfer Zeynep indicates that proportions of Karagöz figures differ for the shows performed before the Sultan, and these $18 \mathrm{~cm}$-tall figures are called "Huzur." ${ }^{27}$ Interviews with Karagöz masters on the dimensions of figures show that they are generally between $30-55 \mathrm{~cm}$ under current conditions. Increasing the size of the figure may cause the limitation of the movements and the aggravation of the rapid movements in the colorful Karagöz figures. Figures with a controlled size also contribute to the performance of the artist. Each moving surface of Karagöz figures connects to another body surface with connection points. This issue is closely related to the size of the figure. The playful

23 Işınsu Ersan, “Gölge Oyunu Estetiğinde Figür Ve Türk Gölge Oyunu: Karagöz” (M.A. Thesis, Dokuz Eylül University, 2011), 178.

24 Ünver Oral, Karagöz ve Plastik Tekniği (İstanbul: Kitabevi, 2012), 29-30.

25 Sevin, Türk Gölge Oyunu, 2.

26 Enver Behnan Şapolyo, Karagözün Tekniği (İstanbul: Türkiye Yayınevi, 1947), 49.

27 Göl, Colours of Shadow, 18. 
nature of the figure, the fact that the pieces keep each other intact, ensuring that the flip-flopping figures quickly return to their previous positions, and the lockdown of pieces during the show due to the surface curvature may affect the rhythm of the play and distract the audience from the play.

The large number of spectators, with Karagöz starting to be performed in closed areas such as theater halls and the conference halls of schools rather than outdoors, can be considered among the reasons for the change in the standard dimensions of the figures. The proximity of the large audience to the screen was influential in the growth of the dimensions. Karagöz master Emin Şenyer stated that the size of the figures "is around $35 \mathrm{~cm} .{ }^{.28} \mathrm{He}$ also shares the information that the size of some particular figures may vary. Cengiz Samsun stated, "In Karagöz figures, the 33-35 cm dimensions and standards may change in original plays." ${ }^{29}$ Also Akın Kurt stated they have produced " $22-25 \mathrm{~cm}$-tall figures for gift purposes." 30

Figures of substantial sizes are made and exhibited in particular shows. Suat Veral shares his experiences by saying, "Inside the culture centre, I designed a special screen layout allowing $750-1000$ people to follow the play, and I brought together 1 to 1.5-meter-tall figures for the audience." ${ }^{31}$

\subsection{Mold}

Karagöz figure art is the visually expressive aspect of a holistic understanding of art. As a language of expression of visuality, the meeting point with the audience is the screen. From the very beginning, all the identities that exist in Karagöz plays are stylized and designed with their most distinctive features. In the drawings of these images, simplified in wording and style, data on their essential characteristics, characteristics of their work, ethnicity, and religious and geographical features are collected and drawn. Hülya Yücesoy determined that "the rules of anatomy and perspective are not applied in the figures" ${ }^{32}$ for the Karagöz figures from past to present. This situation also finds meaning in the aesthetic value of Karagöz plays. Muhittin Sevilen, the artist Hayali Little Ali, said that the characters that are the subjects of figures in Karagöz plays "appear on the white screen with the characteristics of the tribes they belong to, which are visible with wonderfully strong lines. Their costumes and dresses show the same tribal lines." ${ }^{33}$ For this reason, the patterns and drawings that are the source of

28 Emin Şenyer, Personal Interview 18 April 2020

29 Cengiz Samsun, Personal Interview 26 April 2020.

30 Akın Kurt, Personal Interview 25 July 2020.

31 Suat Veral, Personal Interview 10 August 2020.

32 Hülya Yücesoy, "Başlangıçtan Günümüze Karagöz Hacivat Figürlerinin İllüstrasyon Sanatındaki Yeri," (M.A. Thesis, Halic University, 2013), 169.

33 Muhittin Sevilen, Karagöz (İstanbul: Milli Eğitim Basımevi, 1969), 7. 
the figures of the play are fundamental. For example, Hayali Memduh's "Two-volume drawings consisting of Karagöz figures are in the Atatürk Library Rare Works collection." ${ }^{34}$ These figures are reviewed with the profile body postures, clothing and accessories, and appearances in the drawings.

Contemporary Karagöz masters use the old traditional patterns as a guide, and they also use new samples of figures in line with their understanding of art and design. Whether for show, educational, or touristic purposes, the molding will significantly affect the final look of the figure. The colorful painting is on the screen with all its shapes and lines, creating aesthetic harmony. The patterns and forms passed on from competent masters to the new generation continue to shape the future of Karagöz figures. The art of Karagöz, which has changed rapidly within the current version, developed under different perspectives in the last century with the oral and written knowledge transferred by masters of different schools. The relationship between craft and art occurs mainly in the materials and application methods chosen by the masters to make their figures. Under this heading, traditional teaching carries the mold used by the master to his apprentice under the master-apprentice relationship and training. However, today it is seen that Karagöz masters have created Karagöz and Hacivat figure forms, which bear their unique design identities. It is this change that lies behind the recognition and differentiation of the master's figures. When bringing together innovations with the art of figure-making, the traditional should be known well, and new designs should be thought-out after a design-thinking process with versatile observations and research.

\subsection{Perforation (Nevrekanlama)}

Compared to the educational and touristic figures, the figures for show purposes go through a more detailed technical process during the production stage. In this phase, the mold and the leather of the master's figure design approach both the current and traditional practices. The tools and materials used by the figure master during the cutting stage are for this purpose. In the traditional figure-processing technique, “ perforation of inside lines by using a Nevrekan knife is called Nevrekanlama." ${ }^{35}$ There is no repair or reversal of any error made on the point or lines that will transmit light on the figure's surface. Therefore, when the figure's shadow is on the screen with its colorful and transparent form, it becomes visible. For this reason, by using this traditionally accepted nevrekan, it continues to be practised by masters who still use the traditional production method. Haluk Yüce explains his cutting method, "I use three

34 Osman Ocak, "Sinemadan Önce Beyaz Perde; (Tek Kişilik Dev Kadro Hayali)", Hayal ya da Gerçek Şeyh Küssteri'den Hayali Küçük Ali'ye Karagöz, küratör: Doğanay Erkan (İstanbul: İstanbul Büyükşehir Belediyesi Kültür Varlıkları Daire Başkanlığı Kütüphane ve Müzeler Müdürlüğü Yayınları, 2018), 54.

35 Alpay Ekler, "Karagöz Tasvir Art" Colours of Shadow, ed. Nilüfer Zeynep Özçörekçi Göl, Trans. Berker Tercüme (Ankara: Ministery of Culture and Tourism Publications, 2008), 61. 
different nevrekan knives, as shown by my master: In almond (or drop) form for the eyes, a rectangular nevrekan for pouring, and a nevrekan for the turns." 36
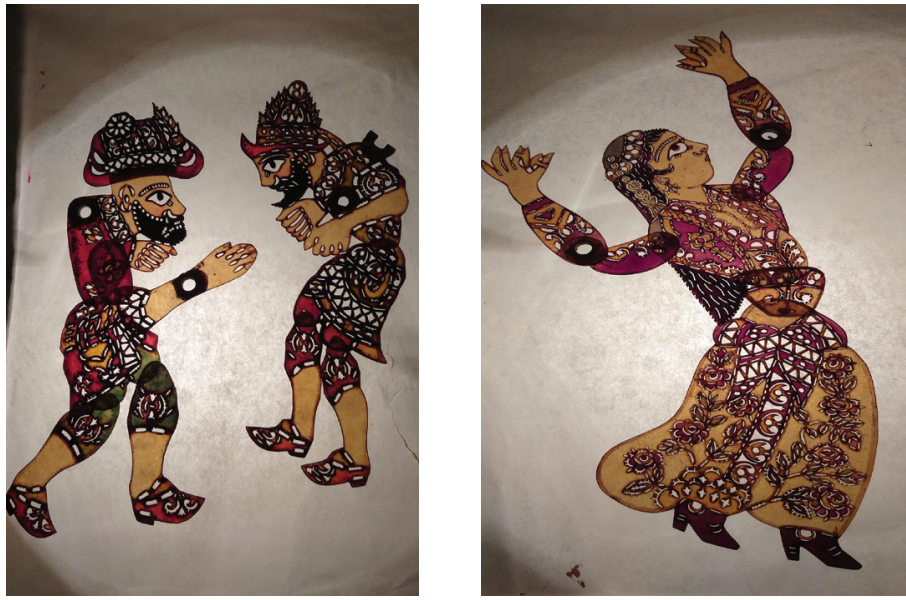

F. 5, F. 6: Karagöz figures of Metin Özlen (M. Özlen Archive, 2020)

Metin Özlen is a master with traditional knowledge in Karagöz figure-making and an artist who also brings innovations to the art of the figures. His works with Nevrekan and "electric nevrekan" 37 are found and exhibited in national and international collections. The figures in (F. 5) and (F. 6) reflect Özlen〉s artistic identity. Metin Özlen, a master craftsman of Karagöz, is also the master of today’s Karagöz masters.

While embroidering fine details on the leather, the electric nevrekan user, depending on his or her mastery of the figure or hand skill, can either enrich or degenerate the figures's lines and patterns visually combined with light.

Burning melts and rapidly pierces leather and plastic-derived materials. The material melts, and the texture and patterns on the surface of the light lines are damaged. As a result of burning, the leather surface becomes charred due to its organic structure. Light lines cut out of the leather with Nevrekan knives give their shape, and technical problems such as melting, crushing, and spilling are not visible on the figure. Consequently, masters who have reached the level of expertise and manage the machines and tools with utmost care must make all cutting and drilling processes on the figure. 


\subsection{Coloring}

The coloring techniques used in Karagöz figures technically differ among figure masters, as does the use and design of patterns. Color is one of the most important points of Karagöz figures. A light source is needed for the color to be perceived visually. Although light is under a different category, the light source gains importance from time to time while evaluating color effects.

The techniques and methods used while coloring Karagöz figures are present in applications with different views. For this reason, it is possible to see a variety of dyes on the figures. These dyes can be defined as natural inks. Natural colored paints traditionally used in Karagöz figures are visible on the screen in pastel tones.

Natural binders are present in the paint for the binding and adherence of these paints. Figures painted with this type of coloring method fade over time. For example, according to Alpay Ekler, "Natural dyes change in time and lose value under the light. This change also provides colours, the softening of inter-changing, an increase of three-dimensional perception, and a gaining of a mystic appearance." ${ }^{38}$ Metin Özlen defends the view that in Karagöz, "raw colors are not used in figures." ${ }^{39}$ Enver Benhan Sapolyo conveys that white, transparent camel leather is applied with madder and the colors these dyes create on the leather are stunning. ${ }^{40}$

Uğur Göktaş shares the following information,

"They preferred root dyes in old dyeing. In addition to being pastel colors, the most important feature of madder is that it penetrates the leather and is not superficial. Today, tile inks are in use for the dyeing process. Since tile inks colors are very bright and do not penetrate the mold on the surface of the leather, they do not work well. In order to prevent the figure from being worn over time and to protect the colors, a little bit of olive oil is applied on it after the contour process is complete." ${ }^{41}$

In applications made with natural dyes on leather, it is necessary to wait for a while for it to absorb the paint after each coat is applied. This application, applied on both the front and the back of the figure, fixes the color on the leather's organic structure. Therefore, when the figure's surface is touched, the colorant does not suffer a visual loss due to moisture on the hands or surfaces because the color is fixed into the leather by the master with utmost patience.

Currently, another method frequently used is chemical-based paints, used in new trials. Liquid dyes, which are among artistic paints used in coloring Karagöz figures,

38 Alpay Ekler, Colours of Shadow, 61.

39 Metin Özlen, Personal Interview 21 July 2020.

40 Şapolyo, Karagözzün Tekniği, 48-49.

41 Uğur Göktaş, Dünkü Karagöz, (İzmir: Akademi Kitabevi, 1992), 78. 
attract attention with their frequency of use. Among the reasons for the preference of these inks are the wide range of colors and the ready-to-use vivid and bright color palette. "Bright and vivid colors are loved and preferred by children, but the use of these colors together and in large areas, disturb the eye and negatively affects the user experience." ${ }^{42}$

When figures made using such industrial inks are touched with sweaty or moist fingers, the paint tends to release itself from the surface. In addition, Karagöz master Hasan Hüseyin Karabağ said, "Sometimes such paints can color the screen. Especially if the paint is not dry or if it comes in contact with moisture." ${ }^{\prime 3}$ It is among the reasons that masters applied shellac or a thin layer of varnish on the figure to protect the colors. In this case, it is important to preserve or fix the colors of the figures made for show purposes.

Using black ink with the help of a thin brush around the shapes determined by light lines highlights the surface areas of each piece by creating a contour that makes the anatomical features of the figure clear. When all parts are intact, all the colored areas also strengthen and clarify the areas in the part-whole relationship. In contemporary figures, Indian or calligraphy ink, permanent marker pens, acetate, and CD pens are also materials for contouring.

In Karagöz figures, the body determines the details that distinguish the parts from each other. These cuts, which are embroidered and have unique shapes, make the flat surfaces of the figures better perceived by the audience, depending on the power of the light. The light sources, from candlelight to oil lamp or torch and from halogen lamps to LED light sources used in traditional teaching, have changed according to the time requirements to differentiate the color values in the figures of each transition. Information obtained from written sources suggests that Karagöz masters have different opinions on this issue.

\subsection{Fixing}

All the elegant and delicate pieces are put together following the traditional teachings and the design of the master. For example, one leg of Karagöz should connect from the front and the other from the back, and planning should be schemed according to the movement limits of the movable parts. The process of sewing the figure according to the center of gravity position of the area, called button, where the figure meets with the rods, is also essential. Karagöz master Alpay Ekler said, "Packing or big size sewing needles, gut strip, and waxed cotton fibres are required for the connection of

\footnotetext{
42 Birsen Çeken and Merve Şenoymak Ersan "Çocuklara Yönelik Grafik Kullanıcı Arayüzü Tasarımının, Kullanılabilirlik ve Eğlence Bakımından Önemi,” Sanat ve Tasarım Journal 10/2 (2019), 230.

43 Hasan Hüseyin Karabağ, Personal Interview 27 April 2020.
} 
pieces and joints. Beeswax is preferred for waxing. Puppeteers prefer a fish line of $0.60 \mathrm{~mm}$ thick for their sets as they are durable." ${ }^{44}$ Karagöz master Orhan Kurt said,

"In the past, saddlers made perfect and strong whipcords used by the artisans who, at that time, used them to cut the figures. Today, not many people are left doing this job. Instead of this, threads made of intestines called "katküt" are available. Considering that the biggest disruption that can occur during a Karagöz show is the breaking of the figure at the joints, the importance of the strength of this thread to be used in sewing will automatically come to light." 45

Hasan Hüseyin Karabakh, one of the contemporary Karagöz figure masters, said, "I prefer fishing line because it is more durable than animal leather or 'katküt'." 46 Emin Şenyer said, "I used a kind of rope called 'Katküt,' but it wears out very quickly, and there may be breaks during the play, so I connect it with a much stronger fishing line, " ${ }^{47}$ while Akın Kurt said, "I tie the joint connections with surgical thread or fishing line." ${ }^{48}$ Cengiz Samsun said, "I pierce the joints with a 'bız', a punching tool, or drill and tie them with waxed-oily thread. In some special cases, I use ribbons that I cut from leather or gut-floss." ${ }^{49}$ Haluk Yüce gives the information, "I use fishing line to tie in joints. ${ }^{" 50}$ Karagöz Master Metin Özlen stated that he uses the traditional "kursak" (a string made from dried animal intestines). ${ }^{51}$

Table 1: Similarities and differences of Karagöz Figures For Touristic Purposes, Karagöz Figures For Educational Purposes, Karagöz Figures For Show Purposes (D.E.Öngen Corsini, 2021)

\begin{tabular}{|l|c|c|c|c|}
\hline $\begin{array}{l}\text { Application of Karagöz Figures according to } \\
\text { their purposes / Use of Material }\end{array}$ & $\begin{array}{c}\text { Karagöz } \\
\text { Figures for } \\
\text { Touristic } \\
\text { Purposes }\end{array}$ & $\begin{array}{c}\text { Karagöz } \\
\text { Figures For } \\
\text { Educational } \\
\text { Purposes }\end{array}$ & $\begin{array}{c}\text { Karagöz } \\
\text { Figures } \\
\text { For Show } \\
\text { Purposes }\end{array}$ & $\begin{array}{c}\text { Current } \\
\text { Karagöz } \\
\text { Figures } \\
\text { For Show } \\
\text { Purposes }\end{array}$ \\
\hline Figure Material "Leather" & $\mathrm{x}$ & $\mathrm{x}$ & $\mathrm{x}$ & $\mathrm{x}$ \\
\hline $\begin{array}{l}\text { Figure Material "Plastic, PVC derivatives, } \\
\text { Cardboard, and etc.." }\end{array}$ & $\mathrm{x}$ & $\mathrm{x}$ & $\mathrm{x}$ & $\mathrm{x}$ \\
\hline Dimensions of "Traditional approach" & $\mathrm{x}$ & $\mathrm{x}$ & $\mathrm{x}$ \\
\hline Dimensions of "Non-traditional approach" & $\mathrm{x}$ & $\mathrm{x}$ & $\mathrm{x}$ \\
\hline Mold "Traditional approach" & & $\mathrm{x}$ & $\mathrm{x}$ & $\mathrm{x}$ \\
\hline Mold "Non-traditional approach" & & & $\mathrm{x}$ \\
\hline Use of Nevrekan "Traditional approach" & & & $\mathrm{x}$ \\
\hline
\end{tabular}

44 Ekler, Colours of Shadow, 59.

45 Kurt, Karagöz'ün Kuralları Karagöz Yapım ve Oynatım Teknikleri, 41.

46 Hasan Hüseyin Karabağ, Personal Interview 27 April 2020.

47 Emin Şenyer, Personal Interview 18 April 2020.

48 Akın Kurt, Personal Interview 25 July 2020.

49 Cengiz Samsun, Personal Interview 26 April 2020.

50 Haluk Yüce, Personal Interview 25 August 2020.

51 Metin Özlen, Personal Interview 25 September 2020. 


\begin{tabular}{|c|c|c|c|c|}
\hline Use of Nevrekan "Non-traditional approach" & $\mathrm{x}$ & $\mathrm{x}$ & & $\mathrm{x}$ \\
\hline Colouring "Traditional approach natural inks" & & $\mathrm{x}$ & $\mathrm{x}$ & $\mathrm{x}$ \\
\hline $\begin{array}{l}\text { Colouring "Non-traditional approach chemical } \\
\text { inks, Analine dyes Markers, etc. " }\end{array}$ & $\mathrm{x}$ & $\mathrm{x}$ & & $\mathrm{x}$ \\
\hline Fixing "Traditional approach" & & $\mathrm{x}$ & $\mathrm{x}$ & $\mathrm{x}$ \\
\hline Fixing "All non-traditional approaches" & $\mathrm{x}$ & $\mathrm{x}$ & & $\mathrm{x}$ \\
\hline
\end{tabular}

Karagöz figure art is classified into three groups: Touristic, Educational, and Show Figures. Under these headings, Table 1 shows similar and different aspects according to the application and methods of Depicted Surface Material, Dimensions of Depictions, Pattern, Nailing, Coloring and Fixing, and Surface materials, which are leather, plastic derivative PVC, and cardboard. While the same materials are also used for educational purposes and in contemporary Karagöz figures, only leather is in use in traditional Karagöz figures for show purposes. The dimensions of the depictions have deviated from the traditional in touristic applications, and both traditional and non-traditional figures are used in educational figures while figures for show purposes use both traditional and non-traditional figure dimensions.

In this change, figures in current applications are made according to the needs of the present setting and play. Regarding patterns of the figures, while it is possible to come across both traditional and non-traditional patterns that exist in the figures for touristic purposes, it is seen that the traditional figure patterns are used in examples in the figures made for educational and show purposes, using the patterns taken from the masters as examples. Nevrekanlama, the cutting of light lines of the figure, is mainly done with a traditional approach when producing educational figures. In contrast, educational figures are made by traditional and non-traditional techniques while the leather is cut and shaped by a traditional nevrekan knife. Both traditional and non-traditional methods are used for current figures for show purposes. While unconventional chemical dyes dominate the coloring of touristic figures, both natural dyes and non-traditional chemical dyes are dominant in educational Karagöz figures. In Karagöz figures for show purposes, there are two different approaches. While dying the figures for traditional show purposes with natural dyes is in the light of traditional teachings, it is possible to see the applications in which current Karagöz figures use natural and chemical dyes and inks. There is a similar situation with the fixing of the portraits. It is frequent to use unconventional methods when fixing the figures for touristic purposes. In the educational figures, both traditional fastening methods and fixings are possible using various metal and plastic materials. While traditional tying and material use continues in Karagöz figures for show purposes, tying in current figures for show purposes is done using many different methods and materials. 
Table 1 classifies Karagöz figures, grouped under three headings, in terms of material usage: colour, form, and approach. This classification reveals the structure of Karagöz figures that changes according to their usage. In other words, the purpose of their use determines the material, form, and approach. This study has classified the data obtained from evaluation and detected a situation assessment. The table has gained importance because it makes this detection concrete.

\title{
4. Aesthetic In Figures For Show Purpose
}

The aesthetic features of Karagöz figures are different from western aesthetic understanding. The difference in the social and mental structure behind it has also affected the aesthetic structure of Karagöz. The colorful pictorial effects of Karagöz figures, their size, scale, positioning, and other defining elements and a Western perspective are different from each other. While the understanding of perspective based on the human eye is dominant in Western painting, this is quite different in the East. Processes in the West, such as those from the Renaissance, which started with the Enlightenment, brought about a world view dominated by the subject and, consequently, the understanding of perspective. In other words, perspective could be possible together with the subject. The Western understanding of aesthetics tends to base the subject within all the rules of detail and perspective. However, there was no experience of the Enlightenment and modernization in the East, and a subject perspective in the Western sense did not develop. Thus, when we evaluate the Karagöz aesthetic understanding from a Western perspective, we will apply a perspective that we hold responsible for the concepts it does not belong to. A different mentality and understanding of culture have produced different aesthetic results. Deliberately avoiding perspective in Karagöz figures could be evaluated within Eastern aesthetics.

\begin{abstract}
"Since the painting surface is not a surface where proximity and distance, smallness and size are organized in a way that dominates the eye that looks at it, there is no background contrast to the central perspective- a unique figure. In contrast, in both scripts and miniatures, the invisible body parts become visible: the front and the back of the face and neck, the fringe and parting of the hair that should only be visible from above. For instance, the noses of figures viewed from the front are long enough to be seen only from above, and many centers that do not fix the eye in a single focus are dominant in all these paintings. In other words, all invisible body details that are visible from the front can be in the same picture. As it is the case for icons, a multi-centered picture, looking at the picture from a single center, constantly transforms the point of view of the eye." 52
\end{abstract}

Karagöz figures are also a visual expression of an aesthetic understanding shaped in the cultural world of this mentality. The traces of this understanding are also present in

52 Pavel Florenski, “Tersten Perspektif,” trans. Yeşim Tükel (İstanbul: Metis Yayınları, 2001), 26. 
the similarity between the forms of figures and miniatures. Accordingly, the figures and the puppets used before the play starts do not have a perspective effect, creating distance, proximity, or size. ${ }^{53}$ When the flat bodies of the figures and the screen used for Karagöz play come close or lean against each other, the colorful shadows become stronger.

The way the bodies stand sideways on flat surfaces creates a feeling of the characters coming face to face during their mutual communication in the play. It is clear that the figure, depicted from the front or side using different body parts, is still sideways. While the body is visible in profile, the eye looks across. Hands and feet may be smaller than the face. Body parts can be both static or mobile. All details on the body are divided linearly and shaped according to the style of the master. On the aesthetics of Karagöz, İsmayıl Hakkı Baltacıŏlu, uses this definition, "Karagöz is not a blindfold imitation of physical individuals but a metaphysics of shapes." ${ }^{44}$
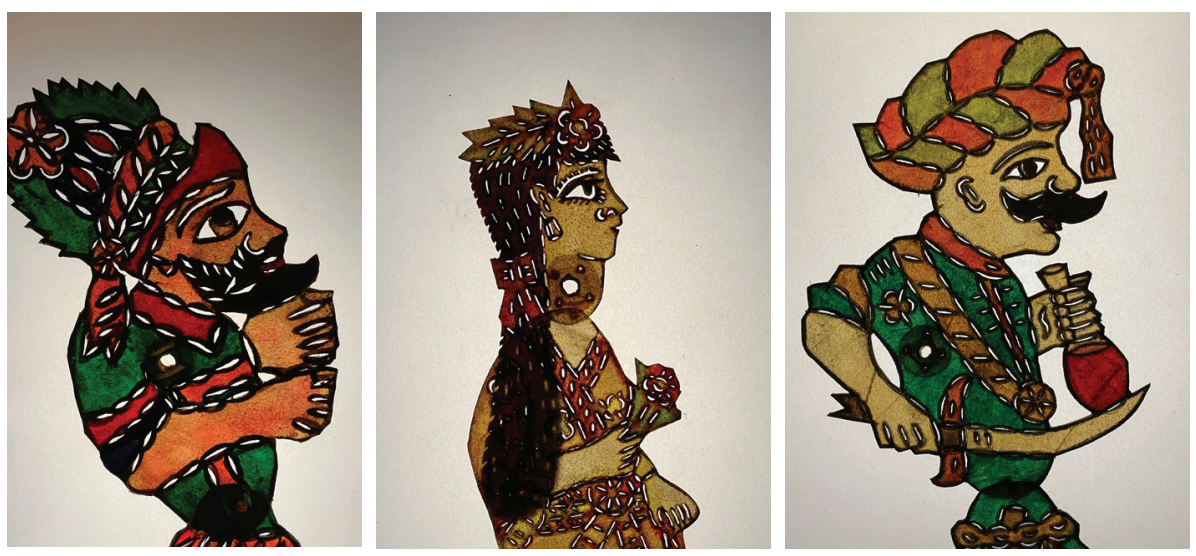

F. 7: "Hacivat" made by Orhan Kurt Inventory No: 540 (Konak Municipality Ümran Baradan Game and Toy Museum Archive, 2020)

F .8: "Zenne" made by Metin Özlen, Inventory No: 546 (Konak Municipality Ümran Baradan Game and Toy Museum Archive, 2020)

F. 9: “Tuzsuz Deli Bekir” by İsmail Hakk1 Özemek, Inventory No: 541 (Konak Municipality Ümran Baradan Game and Toy Museum Archive, 2020)

While creating figures, the master draws and processes the parts of the figure that the artist wants to highlight by adding different features from other areas. For example, eyes are more detailed than hands. The details in the hand and the eye when reviewed within the whole of the figure; the more detailed the hand is, the more elobarate the eye is. However, in the art of Karagöz figures, the eye can be perceived as the most striking area on the body with the shape it has gained when compared to the

53 K. Özlem Alp and Şükrü Balc1, "Karagözde Biçim ve Anlam Kurgusu,” e-Journal of New World Sciences Academy 4/3 (2009), 27.

54 İsmayıl Hakkı Baltacı̆̆lu, Karagöz Tekniği ve Estetiği (İstanbul: Kültür Matbaası, 1942), 23. 
ratio of the nose, mouth, face, and body proportions and the brightness it gains when combined with the cutting and light transmittance. Therefore, the audience's attention focuses on the faces of the figures. The perspective and understanding of painting as close to reality as in Western painting are not present here. As seen in (F. 7), (F. 8), and (F. 9), in the Eastern understanding, the perception of reality felt or desired, not the visuality, is to be emphasized. Miniatures can be an excellent example of this situation. In Karagöz, similar to miniatures, the character standing out can be portrayed as really big even if it is not physically possible. Its size also varies according to the importance of the character. The features of a figure, formed in the scope of a cartoon, make the audience laugh, think, and even help them remember the figure. The joints providing the size of the gestures also connect the body, contributing to the visual creation. For example, the hand can be smaller than the eye.

Stylization, shaping, and style gather standard characteristic features together. In Karagöz figures, all visuals reflected on the screen are subject to the master's style and, therefore, designed with a typical style by omitting the shapes' details. Joining distinctive features, anatomical structures, posture structures, and connection points establish these features.

This situation closely relates to the perception of reality. For example, just like in the eye structure in the Zenne character, hands, figures, and body structures serve the whole within the typical visual stylization of the figure. The unification of all the figures of the play in front of the screen with the traditional painting made in the same style by the same master creates a common language unity with the simplified stylization free of excesses.

Cengiz Samsun referred to the future with this explanation, "There are basic features that are at the basis of Karagöz figures, which, in my opinion, give them their aesthetic value. Drawing technique, processing techniques, coloring, articulation methods, dimensions, etc. Some people define this as 'naive painting, some as primitive or folk painting, and some as miniature, etc.' Whatever it is, I call it the Karagöz dream spirit; I try to catch and protect it." ${ }^{\prime 5}$

\section{Conclusion}

Karagöz is the reflection of Turkish society presented on the screen. Its rich cultural heritage has also taken its place in world art. The traditional Turkish shadow play Karagöz reflects the human being with its values and how it processes events and life in the company of its colorful shadows. The most important figures of Karagöz continued their existence by combining traditional teachings with current ones. It has changed from past to present but has preserved its cultural and visual characteristics. 
There has been an attempt to pass on the figures, which are the visual power of the Karagöz shadow play, to new generations with their centuries-old past and new production purposes encountered in current conditions. Karagöz figures are made for touristic, educational, and show purposes. It is clear that when examining these figures made for different purposes, different methods are purposefully applied to preserve the subtleties of the art of Karagöz.

Today, masters interested in the art of Karagöz figures are trained not only through the master-apprentice relationship but also through training provided by universities and different educational institutions. It is vital to learn the art of the figures by internalizing the contents of the art of the figures, every stage of which requires effort and deep learning rather than just enthusiasm. Therefore, patience and respect are indispensable for the art of figure-making.

In this world where information spreads rapidly, the melting labor force and economic changes have made it challenging to obtain the necessary materials for figures. Due to the rarity of leather and its cost, PVC plastic derivative surfaces, industrial-type inks, and other materials serve as alternatives. Preserving the original, cultural, and aesthetic features of Karagöz is essential when using these materials. This sensitivity can carry Karagöz art into the future. Otherwise, insisting on using certain materials may make it impossible to keep this art alive.

The apprentices of masters of different schools, today's masters, and a new generation of apprentices are the people who will keep this art alive. For this reason, it is necessary to find the correct information in order for the Karagöz figure art to reach future generations without degeneration. With academic education, techniques and methods of this art are to be found, and traditional knowledge should be included in this process. With such an understanding, the training of Karagöz figure-making masters could be long-lasting.

Karagöz, an essential element of the world's cultural heritage, can be carried to the future for touristic, educational, and show purposes by keeping its cultural heritage in line with the recommendations mentioned above. Important heritage from the past should be blended with today's conditions and carried into the future. At this point, academic education is as important as the experience of Karagöz masters. More shows can keep Karagöz alive and ensure its national and international recognition. The Karagöz play has a structure that can handle current events, paving the way for being performed today. Therefore, since new figures will be needed, it will pave the way for different trials.

The purpose of this study on the method, material, and purposes was to suggest a guiding classification in transferring Karagöz figures to future generations. At this point, 
the study includes specific findings and suggestions. New research and studies are needed for Karagöz play to keep their cultural characteristics, to update themselves, and to carry them into the future. Therefore, this study may open the door to new studies in the field.

\footnotetext{
Peer-review: Externally peer-reviewed.

Conflict of Interest: The author has no conflict of interest to declare.

Grant Support: The author declared that this study has received no financial support.

Hakem Değerlendirmesi: Dış bağımsız.

Çıkar Çatışması: Yazarlar çıkar çatışması bildirmemiștir.

Finansal Destek: Yazarlar bu çalışma için finansal destek almadığını beyan etmiştir.
}

\section{References/Kaynakça}

Alp, K. Özlem and Şükrü Balcı. "Karagözde Biçim ve Anlam Kurgusu." e-Journal of New World Sciences Academy 4/3 (2009): 23-32.

And, Metin. Dünyada ve Bizde Gölge Oyunu. Ankara: Türkiye İş Bankası Kültür Yayınları, 1977.

And, Metin. Geleneksel Türk Tiyatrosu. İstanbul: İnkılâp Kitabevi, 1985.

Baltacıŏlu, İsmayı1 Hakkı. Karagöz Tekniği ve Estetiği. İstanbul: Kültür Matbaası, 1942.

Çeken, Birsen and Merve Şenoymak Ersan. "Çocuklara Yönelik Grafik Kullanıcı Arayüzü Tasarımının, Kullanılabilirlik ve Eğlence Bakımından Önemi. ” Sanat ve Tasarım Journal 10/2 (2019): 216-233.

Eken, Yasemin. “Bursa İli Karagöz Müzesinde Yapılan Deri Tasvirlerinin İncelenmesi” M.A. Thesis, Gazi University, 2020.

Ekler, Alpay. "Karagöz Tasvir Art” Colours of Shadow. Ed. Nilüfer Zeynep Özçörekçi Göl. Translation Berker Tercüme. Ankara: Ministery of Culture and Tourism Publications, 2008.

Ersan, Işınsu. "Gölge Oyunu Estetiğinde Figür Ve Türk Gölge Oyunu: Karagöz” M.A. Thesis, Dokuz Eylül University, 2011.

Florenski, Pavel. Tersten Perspektif. Translated by Yeşim Tükel. İstanbul: Metis Yayınları, 2001.

Göktaş, Uğur. Dünkü Karagöz. İzmir: Akademi Kitabevi, 1992.

Göl, Nilüfer Zeynep Özçörekçi. "Turkish Shadow Theatre Karagöz” Colours of Shadow. Ed. Nilüfer Zeynep Özçörekçi Göl, Translated by Berker Tercüme (Ankara: Ministery of Culture and tourism Publications, 2008.

İvgin, Hayrettin. Karagöz ve Kukla Sanatımız. Ankara: Ekip Grafik Matbaa Hizmetleri Tic. ve San. Ltd. Şti., 2000.

Kurt, Orhan. Karagöz'ün Kuralları Karagöz Yapım ve Oynatım Teknikleri. İstanbul: Lale Yayınc1lı, 2015. Nutku, Özdemir. Dünya Tiyatrosu Tarihi. Vol:1. İstanbul: Remzi Kitabevi, 1985.

Ocak, Osman. "Sinemadan Önce Beyaz Perde; Tek Kişilik Dev Kadro Hayali)," Hayal ya da Gerçek Şeyh Küşteri'den Hayali Küçük Ali’ye Karagöz. Küratör: Doğanay Erkan. İstanbul: İstanbul Büyükşsehir Belediyesi Kültür Varlıkları Daire Başkanlığı Kütüphane ve Müzeler Müdürlüğü Yayınları, 2018.

Oral, Ünver. Karagöz ve Plastik Tekniği. İstanbul: Kitabevi Yayınları, 2012. 
Öter, Zafer and Osman N. Özdoğan. "Kültür Amaçlı Seyahat Eden Turistlerde Destinasyon İmaj1: Selçuk-Efes Örneği.” Anatolia: A Journal of Tourism Research 16/2 (2005): 127-138.

Özdemir, Melda and Yasemin Eken. "Bir El Sanatları Ürünü Olarak Karagöz Tasvirlerinin Yapımı Ve Hayali Şinasi Çelikkol'un İcra Geleneğindeki Yeri." Idil Journal of Art and Language 9/75 (2020): 1599-1609.

Sakaoğlu, Saim. Türk Gölge Oyunu Karagöz. Ankara: Akçağ Yayınları, 2003.

Sevin, Nureddin. Türk Gölge Oуиnu. İstanbul: Milli Eğitim Bakanlığı Büyük Türk Yazarları ve Şairleri Komisyonu Yayınları, 1968.

Sevilen, Muhittin. Karagöz. İstanbul: Milli Eğitim Basımevi, 1969.

Sönmez, Sevengül. Karagöz Kitabı. İstanbul: Kitabevi Yayınları, 2000.

Şapolyo, Enver Behnan. Karagözün Tekniği. İstanbul: Türkiye Yayınevi, 1947.

Tan, Nail. "Karagöz Sanatçısı Ragıp Tuğtekin'le bir Konuşm.” Yıktın Perdeyi Eyledin Vîran Yapı Kredi Karagöz Koleksiyonu. Ed. Sabri Koz. İstanbul: Yapı Kredi Yayınları, 2004.

Taş, Hülya. “Günümüz Bursa'sında Karagöz.” Uludağ University Fen-Edebiyat Fakültesi Sosyal Bilimler Journal 8/12 (2007): 133-146.

Temel, Süreyya. "Sahne Tasarımında Bir Anlayış; Az Aslında Çoktur.” International Journal of Interdisciplinary and Intercultural Art 3/6 (2018): 205-214.

Ünal, Murat. “Türk Halk Tiyatrosunun Sinemaya Etkileri.” Art-Sanat 9 (2018): 337-349.

Ünlü, Aslıhan. Türk Tiyatrosunun Antropolojisi. Ankara: Aşina Kitaplar, 2006.

Yücesoy, Hülya. "Başlangıçtan Günümüze Karagöz Hacivat Figürlerinin İllüstrasyon Sanatındaki Yeri.” M.A. Thesis, Halic University, 2013.

“Geleneksel El Sanatları Online Satış Web Sitesi”. Accessed 24 September 2020 https://www.ges. gov.tr/tr/.

UNESCO Türkiye Milli Komisyonu. Accessed 23 September 2020 https://www.unesco.org.tr/ Pages $/ 126 / 123 /$ UNESCO-\%C4\%B0nsanl\%C4\%B1\%C4\%9F\%C4\%B1n-Somut-Olmayan$\mathrm{K} \% \mathrm{C} 3 \% \mathrm{BClt} \% \mathrm{C} 3 \% \mathrm{BCrel-Miras} \% \mathrm{C} 4 \% \mathrm{~B} 1-$ Temsil\%C3\%AE-Listesi

\section{Interviews with Karagöz Masters}

I:1: Karabăg, Hasan Hüseyin, 27 April 2020 / Born in 1967, Karagöz master, İstanbul - Turkey.

I:2: Kurt, Akın, 25 July 2020 / Born in 1968, Karagöz master, İstanbul - Turkey.

I:3: Özgökbel, Deniz, 24 September 2020 / Born in 1978, Karagöz master, member of UNIMA, İzmir - Turkey.

I:4: Özlen, Metin, 21 July 2020 and 25 September 2020 / Born in 1940, Karagöz master, member of UNIMA, İstanbul - Turkey.

I:5: Samsun, Cengiz, 26 April 2020 / Born in 1978, puppet and Karagöz master, member of UNIMA, İstanbul- Turkey.

I:6: Şenyer, Emin, 18 April 2020 / Born in 1961, Karagöz master, İstanbul - Turkey.

I:7: Veral, Suat, 10 August 2020 / Born in 1966, Karagöz master, member of UNIMA, İstanbul - Turkey.

I:8: Yüce, Haluk, 25 August 2020 / Born in 1954, puppet and Karagöz master, member of UNIMA, Ankara - Turkey. 
